\title{
Rancang Bangun Robot Pengangkut Sampah Pintar Menggunakan Mikrokontroler
}

\author{
Clara Robert Pangestu \\ Jurusan Sistem Komputer,FTI Universitas Andalas Limau Manis Kec. Pauh, Kota Padang, Sumatera Barat 25163 INDONESIA
}

\section{ARTICLE INFORMATION}

Received: August $28^{\text {th }}, 2019$

Revised: September $17^{\text {th }}, 2019$

Available online: September 30 $0^{\text {th }}, 2019$

\section{KEYWORDS}

Garbage, Robot, Ultrasonic Sensor, MQ-4

Sensor, Photodioda Sensor.

\section{CORRESPONDENCE}

Phone: 0895603728775

E-mail: clararobertpangestu@gmail.com

\section{A B S T $\mathbf{R}$ A $\mathbf{C}$ T}

\begin{abstract}
Humans are living things that like all things that are clean and beautiful to look at, including environment around them. Nowadays, there are many people that conscious and care about environmental hygiene, but there are many of them that do the otherwise. Managing trash can in their residential area is one form of human awareness of environmental sanitation. Human's responsibility in keeping their health and the environment is not only to dispose of trash in its place but also to manage a fully loaded trash can. Because of the waste management problem, the writer made a smart garbage transport robot, which is a fully loaded trash can or a trash can that has methane in it can move automatically from a residential area to its landfill. Components that used to detect the condition of a trash can are Ultrasonic sensor that used to identifies a fully loaded trash can; MQ-4, a methane gas sensor to detect methane gas's level in the trash can; and photodiode sensor for the automatic trash can robot's line tracking to the landfill. The success rate of garbage transport robot is 4 out of 4 trials.
\end{abstract}

Keywords: Garbage, Robot, Ultrasonic Sensor, MQ-4 Sensor, Photodioda Sensor.

\section{PENDAHULUAN}

Manusia adalah makluk hidup yang menyukai semua hal yang bersih serta indah untuk dipandang salah satunya adalah lingkungan disekitarnya. Pada saat sekarang ini banyak manusia yang sadar serta peduli dengan kebersihan lingkungan tetapi banyak juga manusia yang melakukan hal sebaliknya. Mengelola tempat sampah yang berada didaerah tempat tinggal mereka sendiri merupakan salah satu bentuk kesadaran manusia terhadap kebersihan lingkungan.

Sampah tentunya menjadi sesuatu yang sangat mengganggu untuk semua manusia karena sampah bukan hanya dapat mencemari lingkungan saja tetapi juga dapat mengganggu kesehatan manusia. Tugas manusia dalam menjaga kesehatan dan lingkungannya sendiri bukan hanya sekedar membuang sampah pada tempatnya tetapi juga dalam mengelola tempat sampah yang telah terisi penuh. Petugas kebersihan yang bertugas biasanya akan mengumpulkan semua sampah pada setiap rumah yang dilaluinya atau bagi daerah yang tidak dapat dilalui oleh petugas biasanya membuang sendiri tempat sampah yang telah terisi penuh oleh sampah ke tempat pembuangan akhir sampah daerah masing-masing untuk dapat diambil oleh petugas kebersihan kota. Tugas penting inilah yang kadang dilupakan serta diabaikan oleh manusia dalam menjaga kebersihan lingkungan disekitarnya. 
Pada penelitian sebelumnya telah dirancang sebuah sistem yang dapat memonitoring kapasitas tempat sampah melalui smartphone android, sistem ini menggunakan Arduino UNO sebagai pengolah data, sensor berat dan sensor jarak sebagai parameter tempat sampah penuh. Hasil dari sensor tersebut kemudian dikirimkan ke web server untuk diolah dan dikirimkan ke smartphone android petugas kebersihan sebagai pemberitahuan untuk segera menangani tempat sampah yang telah penuh [1]. Pada penelitian sebelumnya juga telah dirancang sebuah sistem yang hampir sama yaitu sistem yang dapat memonitoring kapasistas tempat sampah lalu hasilnya akan ditampilkan pada LCD sistem ini menggunakan Arduino Mega 2560 Rev3 sebagai pengontrol, Sensor PING HC-SR04 sebagai pendeteksi kedatangan objek dan juga pendeteksi kapasitas tempat sampah dan LCD sebagai alat menampilkan kapasitas tempat sampah [2]. Pada penelitian sebelumnya juga dirancang tempat sampah dengan penutup tempat sampah otomatis serta dilengkapi indikator volume untuk monitor isi tempat sampah, sehingga pengguna tidak perlu menyentuh penutup saat membuka dan memeriksa apakah tempat sampah sudah penuh atau tidak [3]. Tetapi ketiga sistem ini hanya sampai menginformasikan hasil monitoring dari tempat sampah untuk membuang sampah tetap dilakukan secara manual ke tempat pembuangan. Karena permasalahan pengelolahan sampah diatas perlu dirancang sebuah robot pengangkut sampah pintar yaitu tempat sampah yang sudah terisi penuh atau telah mengandung kadar gas metana dapat berpindah secara otomatis dari rumah warga menuju tempat pembuangan akhir sampah suatu pemukiman. Tempat sampah yang sudah dalam keadaan kosong juga akan kembali secara otomatis dari tempat pembuangan akhir menuju rumah warga kembali. Gas metana adalah gas dengan emisi gas rumah kaca 23 kali lebih ganas dari karbondioksida yang berarti gas metana merupakan kontributor yang sangat buruk bagi pemanasan global yang sedang berlangsung. Sistem ini dirancang bukan hanya untuk mempermudah manusia dalam mengelola tempat sampah di rumahnya tetapi juga untuk mempermudah petugas kebersihan dalam mengumpulkan sampah dari setiap rumah.

\section{Sampah}

Sampah adalah sisa aktivitas dari manusia dan hewan yang berbentuk zat padat dan dibuang, karena sudah tidak bernilai bagi pemiliknya. Sampah sendiri memiliki banyak jenis, banyak sumber dan memiliki karakteristik yang khas, dari beberapa arti sampah mempunyai ciri-ciri yaitu [4] :

1. Sampah adalah bahan sisa, baik bahan-bahan yang sudah tidak digunakan lagi (barang bekas) maupun bahan yang sudah diambil bagian utamanya.

2. Dari segi sosial ekonomis, sampah adalah bahan yang sudah tidak ada harganya.

3. Dari segi lingkungan, sampah adalah bahan buangan yang tidak berguna dan banyak menimbulkan masalah pencemaran dan gangguan pada kelestarian lingkungan. Jenis Sampah dibagi menjadi 3 (tiga), yaitu sampah perkotaan, sampah industri dan sampah berbahaya.

\section{Sensor Ultrasonik HC-SR04}

Sensor jarak ultrasonik HC-SR04 adalah sensor $40 \mathrm{KHz}$. HCSR04 merupakan sensor ultrasonik yang dapat digunakan untuk mengukur jarak antara penghalang dan sensor [5]. Pada Gambar 1 dapat dilihat bentuk dari Sensor Ultrasonik.

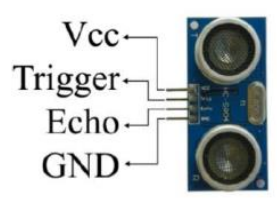

Gambar 1 Sensor Ultrasonik [5]

HC-SR04 memiliki 2 komponen utama sebagai penyusunnya yaitu ultrasonik transmitter dan ultrasonik receiver. Fungsi dari ultrasonic transmitter adalah memancarkan gelombang ultrasonik dengan frekuensi $40 \mathrm{KHz}$ kemudian ultrasonic receiver menangkap hasil pantulan gelombang ultrasonik yang mengenai suatu objek [5]. Datasheet Sensor Ultrasonik dapat dilihat pada table 1 .

Tabel 1 Datasheet Sensor Ultrasonik[6]

\begin{tabular}{|l|l|}
\hline Working Voltage & DC 5 V \\
\hline Working Current & $15 \mathrm{~mA}$ \\
\hline $\begin{array}{l}\text { Working } \\
\text { Frequency }\end{array}$ & $40 \mathrm{~Hz}$ \\
\hline Max Range & $4 \mathrm{~m}$ \\
\hline Min Range & $2 \mathrm{~cm}$ \\
\hline Measuring Angle & 15 degree \\
\hline $\begin{array}{l}\text { Trigger } \\
\text { Signal }\end{array}$ & $10 \mathrm{uS}$ TTL pulse \\
\hline $\begin{array}{l}\text { Echo } \\
\text { Signal }\end{array}$ & $\begin{array}{l}\text { Onput TTL lever signal and } \\
\text { the range in proportion }\end{array}$ \\
\hline Dimension & $45 * 20 * 15$ mm \\
\hline
\end{tabular}

\section{Sensor Gas Metana MQ-4}

MQ-4 adalah komponen elektronika untuk mendeteksi kadar gas alam terkompresi / CNG (compressed natural gas) — utamanya mengandung gas metana (metana, $\mathrm{CH} 4$ ) yang merupakan bentuk paling sederhana dari hidrokarbon. Walaupun tidak bersifat racun, gas metana dapat berbahaya karena mudah terbakar (combustive / flammablegas). Gas ini tidak berbau dan tidak 
berwarna, menjadikannya sulit untuk dideteksi secara langsung oleh manusia [7]. Sensor MQ-4 merupakan sensor yang sangat sensitif terhadap CNG dan dapat mendeteksi konsentrat gas alam di udara mulai dari 200 ppm hingga 10.000 ppm. Keluaran sensor ini berupa resistansi analog yang dengan mudah dapat dikonversi menjadi tegangan dengan menambahkan satu resistor biasa. Dengan mengkonversi impedansi ini menjadi tegangan, hasil bacaan sensor dapat dibaca oleh pin ADC (analog to digital converter) pada mikrokontroler [7].

PPM (parts per million) umumnya digunakan sebagai ukuran tingkat kecil polutan di udara, air, cairan tubuh, dan lain-lain. PPM adalah rasio massa antara komponen polutan dan larutan. Satuan konsentrasi ini yang sering dipergunakan dalam Kimia Analisa. Satuan ini sering digunakan untuk menunjukkan kandungan suatu senyawa dalam suatu larutan misalnya kandungan garam dalam air laut, kandungan polutan dalam sungai, atau kandungan yang lainnya [7]. Pada Gambar 2 dapat dilihat bentuk dari Sensor Gas Metana MQ-4

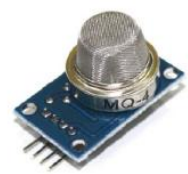

Gambar 2 Sensor Gas Metana HQ-4 [7]

Berdasarkan datasheet dibawah ini sensor gas MQ 4 terdiri dari 6 kaki pin yaitu pin input, 2 pin GND dan sisanya pin VCC [7]. Datasheet Sensor MQ-4 dapat dilihat pada gambar 3.

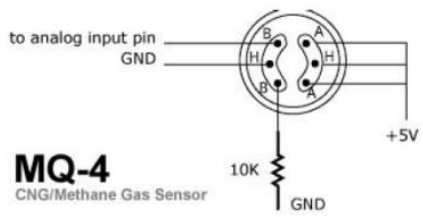

Gambar 3 Datasheet Sensor Gas Metana HQ-4 [7]

Metana dalam jumlah berlebih bisa sangat berbahaya bagi lingkungan hidup, terutama kesehatan manusia. Dikenal sebagai "asphyxiate sederhana", metana menggantikan oksigen dalam ruang kecil tertutup. Oksigen minimum yang dibutuhkan untuk bernapas adalah $18 \%$, namun bila lebih rendah dari $10 \%$ dapat berakibatfatal[8].

Bila tercampur dengan zat lain, metana juga berpotensi beracun. Bila gas alam, yang mengandung $97 \%$ metana, dibakar tanpa pengaturan ventilasi yang tepat, karbon monoksida yang dihasilkannya bisa menyebabkan kematian dalam waktu dua jam. Pada kadar yang tinggi bisa membunuh hanya dalam waktu tiga menit. Dilaporkan 500 orang meninggal karena keracunan karbon monoksida setiap tahunnya di Amerika [8].

\section{Arduino UNO}

Arduino UNO adalah board berbasis mikrokontroler pada ATmega328. Board ini memiliki 14 digital input / output pin (dimana 6 pin dapat digunakan sebagai output PWM), 6 input analog, $16 \mathrm{MHz}$ osilator kristal, koneksi USB, jack listrik tombol reset. Pin-pin ini berisi semua yang diperlukan untuk mendukung mikrokontroler, hanya terhubung ke komputer dengan kabel USB atau sumber tegangan bisa didapat dari adaptor AC-DC atau baterai untuk menggunakannya [9]. Pada Gambar 4 dapat dilihat bentuk dari Arduino Uno.

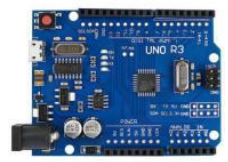

Gambar 4 Arduino Uno [9]

Tabel 2 Datasheet Arduino Uno [9]

\begin{tabular}{|l|l|}
\hline Mikrokontroler & ATMega328 \\
\hline Operasi Voltage & $5 \mathrm{~V}$ \\
\hline Input Voltage & $7-12 \mathrm{~V}$ (rekomendasi) \\
\hline Input Voltage & $6-20 \mathrm{~V}$ (limit) \\
\hline I/O & 14 pin ( 6 pin untuk PWM ) \\
\hline Arus & $50 \mathrm{~mA}$ \\
\hline Flash Memory & $32 \mathrm{~KB}$ \\
\hline Bootloader & SRAM $2 \mathrm{~KB}$ \\
\hline EERPROM & $1 \mathrm{~KB}$ \\
\hline Kecepatan & $16 \mathrm{MHz}$ \\
\hline
\end{tabular}

\section{Line Follower Robot}

Robot adalah suatu benda dengan kemampuan bergerak atau bekerja secara otomatis yang terbuat dari gabungan beberapa sistem elektronika. Line follower robot adalah suatu robot yang bertugas mengikuti suatu garis dengan rute yang sudah ditentukan. Line follower robot bergerak secara otomatis dan terprogram menggunakan suatu chip mikrokontroler. Proses pergerakan robot dikontrol oleh motor yang terhubung dengan mikrokontroler yang secara otomatis mengendalikan laju putaran motor. Proses pergerakan motor dipengaruhi oleh sensor garis yang berupa photo sensor sebagai penjejak warna garis [10]. 
Menurut Soebhakti (2007) ada beberapa bagian yang harus terpenuhi dalam pembuatan sebuah line follower robot. Setiap bagian memiliki fungsi-fungsi tersendiri agar robot dapat bekerja dengan baik [10].

\section{Sensor Pada Line Follower Robot}

Sensor ini memiliki fungsi sebagai pendeteksi garis pada lintasan robot. Komponen penyusun dari sensor ini adalah led infra merah dan photodioda. Led infra merah berfungsi sebagai pemancar (transmitter) dan photodioda sebagai penerima (receiver) Pemasangan sensor ini adalah saling sejajar karena memanfaaatkan efek pemanculan cahaya dari pemancar ke penerima [10]. Pada Gambar 5 dapat dilihat bentuk dari Sensor pada Line Follower Robot.
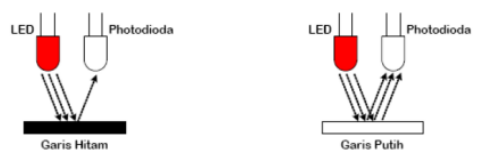

Gambar 5 Sensor Pada Line Follower Robot [10]

Sifat dari photodioda adalah jika semakin banyak cahaya yang diterima, maka nilai resistansi diodanya semakin kecil. Dengan melakukan sedikit modifikasi, maka besaran resistansi tersebut dapat diubah menjadi tegangan. Sehingga jika sensor berada diatas garis hitam, maka tegangan keluaran sensor akan kecil, demikian pula sebaliknya [10].

\section{Mekanik Robot}

Mekanik dibuat dengan tujuan memberikan bentuk kepada robot. Bagian ini berfungsi untuk menggabungkan beberapa bagian robot sehingga menjadi dalam satu kesatuan. Desain dari mekanik robot ini akan mempengaruhi dari kinerja gerakan robot. Untuk mendapatkan hasil yang baik desain robot dibuat seringan mungkin agar robot dapat bergerak dengan lincah [10]. Pada Gambar 6 dapat dilihat bentuk dari contoh rancangan mekanik Line Follower Robot.

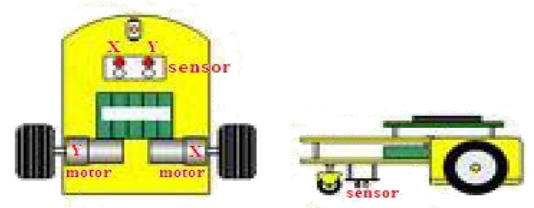

Gambar 6 Contoh Rancangan Mekanik Line Follower Robot

\section{Driver Motor}

Driver motor digunakan untuk menguatkan arus yang masuk ke motor. Terdapat bermacam jenis driver motor dari yang menggunakan transistor sampai dengan IC. Prinsip kerja dari berbagai driver motor sama yaitu mengendalikan laju putaran motor. Kebutuhan jenis driver motor yang digunakan pada pembuatan line follower robot tergantung dari konsumsi arus yang dibutuhkan motor [10].

\section{Push Button}

Saklar merupakan komponen elektronika yang berfungsi untuk menghubungkan dan memutuskan dua titik atau lebih dalam suatu rangkaian elektronika. Salah satu jenis saklar adalah saklar Push button yaitu saklar yang hanya akan menghubungkan dua titik atau lebih pada saat tombolnya ditekan dan pada saat tombolnya tidak ditekan maka akan memutuskan dua titik atau lebih dalam suatu rangkaian elektronika.Saklar push button dapat berbentuk berbagai macam, ada yang menggunakan tuas dan ada yang tanpa tuas. Saklar push button sering diaplikasikan pada tombol-tombol perangkat elektronik digital. Salah satu contoh penggunaan saklar push ON adalah pada keyboard komputer, keypad printer, matrik keypad, tombol kontrol pada DVD player dan lain sebagainya [11].

\section{PWM}

Pulse Width Modulation (PWM) secara umum adalah sebuah cara memanipulasi lebar sinyal yang dinyatakan dengan pulsa dalam suatu perioda, untuk mendapatkan tegangan rata-rata yang berbeda. Beberapa Contoh aplikasi PWM adalah pemodulasian data untuk telekomunikasi, pengontrolan daya atau tegangan yang masuk ke beban, regulator tegangan, audio effect dan penguatan, serta aplikasi-aplikasi lainnya.Aplikasi PWM berbasis mikrokontroler biasanya berupa, pengendalian kecepatan motor DC, Pengendalian Motor Servo, Pengaturan nyala terang LED [12].

\section{METODOLOGI PENELITIAN}

Penelitian ini menggunakan jenis penelitian system development (pengembangan sistem). Pengembangan sistem dilakukan dengan menambahkan beberapa komponen elektronika. Komponen dan alat-alat tersebut antara lain adalah sensor ultrasonic, sensor MQ 4, sensor photodioda, driver motor, motor dc, roda, push button dan. Powerbank. Pada penelitian ini akan diuji apakah masukan yang diberikan sesuai dengan keluaran yang diinginkan.

\section{Rancangan Alat}


Bentuk rancangan sistem pengangkut sampah pintar dapat dilihat pada Gambar 7.

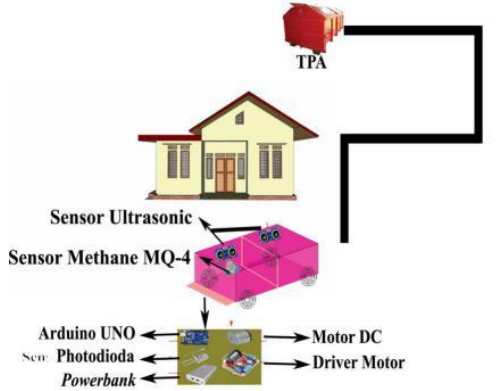

Gambar 7 Rancangan Arsitektur Alat

Perancangan umum sistem dilakukan dengan menggambarkan rancangan perangkat keras sistem secara keseluruhan. Perancangan umum sistem terdapat pada gambar 7, pada rancangan tersebut terdapat tempat sampah berukuran $17 \times 16 \times 22 \mathrm{~cm}$ sebanyak 2 buah yang berada di depan sebuah rumah, tempat sampah pada Gambar 7 juga terdiri dari beberapa perangkat keras yaitu sensor ultrasonik, sensor gas, sensor photodioda, driver motor, motor DC, catu daya, roda, push button dan Arduino UNO. Tempat sampah otomatis akan berjalan menuju tempat pembuangan akhir. Pada Gambar 7 dapat dilihat arsitektur sistem penggumpulan sampah otomatis menggunakan Mikrokontroler.

\section{Perancangan Perangkat Keras}

Perancangan Perangkat Keras terdapat pada gambar 8 pada Sistem pengumpulan sampah otomatis ini menggunakan tiga sensor yaitu sensor ultrasonik, sensor gas MQ-4 dan sensor photodioda. Pada gambar 8 terdapat sensor ultrasonik digunakan untuk mengukur isi dari tempat sampah, sensor gas MQ-4 digunakan untuk mengukur tingkat gas metahana pada tempat sampah sedangkan sensor photodioda digunakan untuk line tracking tempat sampah menuju tempat pembuangan akhir. Pada gambar 8 juga terdapat Motor DC untuk menggerakannya secara otomatis menuju tempat pembuangan akhir. Pada Gambar 8 dapat dilihat skema perancangan komponen hardware sistem.

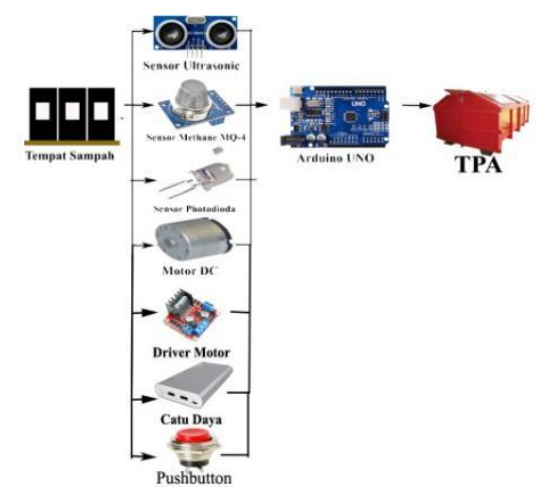

Gambar 8 Skema Perancangan Komponen Hardware Sistem

Secara singkat, prinsip kerja sistem pengumpulan sampah otomatis adalah :

1.Sensor digunakan untuk monitoring tempat sampah serta tempat pembungangan akhir sampah. Sensor yang digunakan adalah sensor ultrasonik dan sensor gas metana MQ-4 untuk memonitoring tempat sampah. Sensor juga digunakan untuk line tracking tempat sampah. Sensor yang digunakan adalah sensor photodioda.

2.Driver Motor dan Motor DC. Driver motor digunakan untuk menguatkan arus yang masuk ke motor. Motor DC digunakan untuk mendukung sistem pengumpulan sampah otomatis agar tempat sampah dapat berjalan mengikuti line tracking menuju tempat pembuangan akhir yaitu berupa bak sampah daerah tersebut.

3.Push Button yaitu saklar yang hanya akan menghubungkan dua titik atau lebih pada saat tombolnya ditekan dan pada saat tombolnya tidak ditekan maka akan memutuskan dua titik atau lebih dalam suatu rangkaian elektronika.

4. Arduino UNO. Data yang didapat dari sensor lalu diproses oleh Arduino Uno.Arduino berguna untuk mengubah dan memproses data analog yang didapatkan dari sensor tadi. Arduino menggunakan Arduino IDE sebagai software untuk memproses data-data tersebut.

5. Catudaya atau sumberdaya yang digunakan untuk sistem adalah Powerbank

\section{Rancangan Proses}

Perancangan pemrograman Arduino Uno terdapat flowchart utama serta flowchart untuk pergerakkan robot, berikut gambar 9 menggambarkan flowchart perancangan pemrograman pada Arduino Uno dan Motor DC. Gambar 9 merupakan alur perancangan program yang akan berjalan pada Arduino Uno. Pada awal program dilakukan inisialisasi terhadap variable yang akan digunakan untuk tahapan berikutnya termasuk komponen line follower. Kemudian didapatkan nilai dari sensor ultrasonik 
dan sensor gas metana MQ-4. Kemudian nilai tersebut diproses sehingga menghasilkan output berupa nilai setiap sensor yang digunakan. Selanjutnya dilakukan pengecekan kondisi apabila tempat sampah telah memenuhi kondisi tersebut tempat sampah akan bergerak secara otomastis menuju tempat pembuangan akhir. Pada Gambar 9 dapat dilihat Flowchart pemograman Arduino Uno.

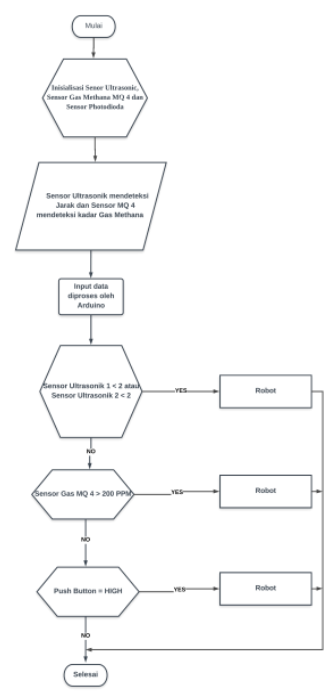

Gambar 9.a Pemograman Arduino UNO

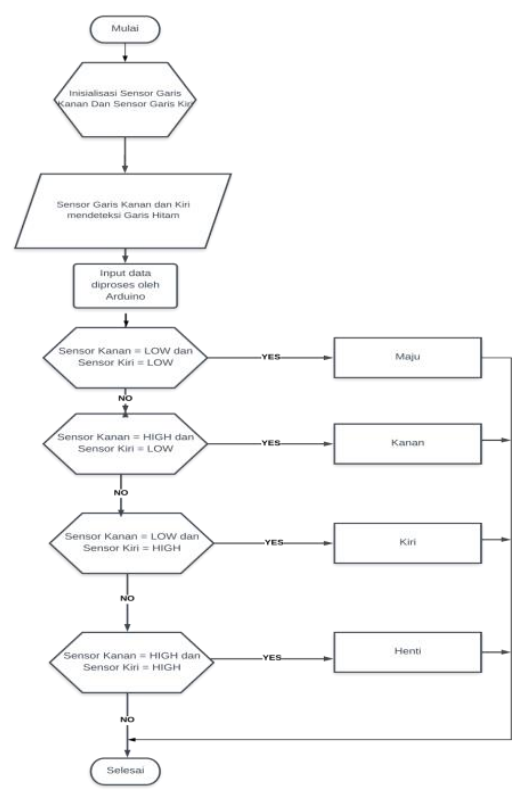

Gambar 9.b Pemograman Motor DC

Gambar 9 Flowchart Pemograman Arduino UNO dan Motor DC

Pada gambar A terdapat flowchart proses secara umum pada arduino sedangkan pada gambar B merupakan flowchart bagian Motor DC yang merupakan alur program robot dalam melakukan line tracking lintasan yang telah ditentukan. Pada awal program dilakukan inisialisasi terhadap variable yang akan digunakan untuk tahapan berikutnya. Kemudian didapatkan nilai dari sensor garis kanan dan sensor garis kiri. Kemudian nilai tersebut https://doi.org/10.25077/jitce.3.02.78-89.2019 diproses sehingga menghasilkan output berupa nilai setiap sensor yang digunakan. Selanjutnya dilakukan pengecekan kondisi apabila nilai digital dari sensor kanan dan sensor kiri bernilai LOW maka robot akan maju apabila hanya sensor kanan yang bernilai HIGH sedangkan sensor kiri bernilai LOW maka robot akan belok kearah kanan dan sebaliknya apabila hanya sensor kiri yang bernilai HIGH sedangkan sensor kiri bernilai LOW maka robot akan belok ke arah kiri, terakhir apabila kedua sensor bernilai HIGH maka robot akan berhenti.

\section{HASIL DAN PEMBAHASAN}

\section{Implementasi Perangkat Keras}

Pada implementasi perangkat keras dirancang sebuah sistem pengangkut sampah otomatis yang menggunakan tiga sensor yaitu sensor ultrasonik, sensor gas MQ-4 dan sensor photodioda. Sensor ultrasonik digunakan untuk mengetahui keadaan tempat sampah telah terisi penuh atau belum terisi penuh, sensor gas MQ-4 digunakan untuk mengukur tingkat gas metana pada tempat sampah sedangkan sensor photodioda digunakan untuk line tracking tempat sampah menuju tempat pembuangan akhir. Tempat sampah pintar ini juga menggunakan Motor DC untuk menggerakannya secara otomatis menuju tempat pembuangan akhir. Pada Gambar 10 dapat dilihat hasil rancangan perangkat keras berupa robot pengumpul sampah.

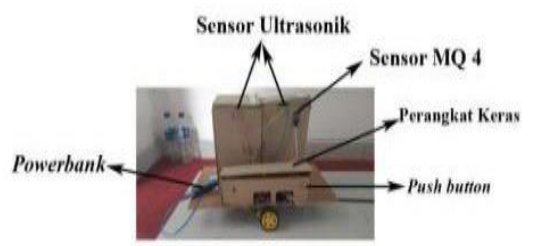

Gambar 10.a Hasil Rancangan Robot Pengumpul Sampah Otomatis Tampak Samping

Pada gambar 10.a yaitu Tampak Samping terlihat ada 2 buah tempat sampah untuk sampah kering dan basah. Pada tempat sampah kering terdapat satu sensor ultrasonik dan untuk sampah basah terdapat satu sensor ultrasonik dan satu sensor MQ-4 untuk memonitoring tempat sampah. Pada gambar juga terdapat Powerbank sebagai catudaya.

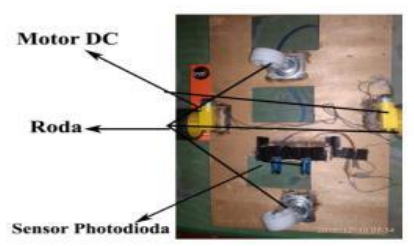

Gambar 10.b Hasil Rancangan Robot Pengumpul Sampah Otomatis Tampak Bawah 
Pada gambar 10.b yaitu Tampak Bawah terdapat dua sensor photodioda sebagai pembaca jalurnya robot, dan motor DC digunakan untuk menggerakan roda robot tersebut.

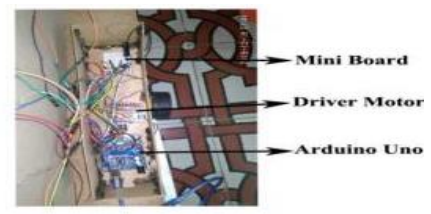

Gambar 10.c Hasil Rancangan Robot Pengumpul Sampah Otomatis Bagian Perangkat Lunak

Dari gambar 10.c yaitu Bagian Perangkat Lunak terdapat Arduino UNO berguna untuk mengubah dan memproses data analog yang didapatkan dari sensor tadi. Lalu ada Motor Driver digunakan untuk menguatkan arus yang masuk ke motordan terakhir Mini Breadboard yang digunakan untuk menghubungkan semua pin VCC dan pin Ground semua sensor.

\section{Denah Jalur}

Jalur yang digunakan dalam perancangan ini menggunakan selotip berwarna hitam. Lebar selotip yang digunakan sebesar $3 \mathrm{~cm}$ mengikuti lebar selotip yang tersedia di pasaran. Pada Gambar 11 dapat dilihat denah jalur dari robot pengumpul sampah.

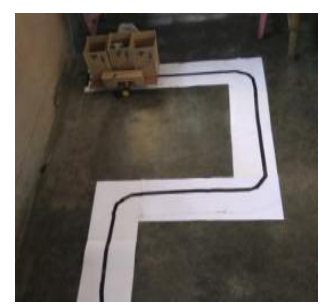

Gambar 11 Jalur Robot

Hasil implementasi jalur robot ditunjukkan pada gambar 11 terdapat garis lurus pada awal jalur sepanjang $84 \mathrm{~cm}$ lalu jalur berubah menjadi belok ke arah kanan dengan panjang jalur $90 \mathrm{~cm}$. Jalur berubah kembali menjadi lurus sepanjang $84 \mathrm{~cm}$ dan dan terakhir kembali berubah menjadi belok ke arah kiri dengan panjang jalur $90 \mathrm{~cm}$. Jadi jarak antara posisi awal dengan posisi akhir adalah $352 \mathrm{~cm}$.

\section{Pengujian Sistem}

Pengujian sistem merupakan proses pengeksekusian sistem perangkat keras dan lunak untuk menentukan apakah sistem tersebut cocok dan sesuai dengan yang diinginkan peneliti. Pengujian dilakukan dengan melakukan percobaan untuk melihat kemungkinan kesalahan yang terjadi dari setiap proses.
Dalam melakukan pengujian, tahapan-tahapan yang dilakukan pertama kali adalah melakukan pengujian terhadap perangkatperangkat inputan yaitu pengujian terhadap sensor-sensor yang ada meliputi Sensor Ultrasonik, Sensor MQ-4, Sensor Photodioda, Motor DC, Roda, Catu Daya, Motor Driver dan Push Button. Kemudian melakukan pengujian secara keseluruhan sistem kontrol robot.

\section{Pengujian Sensor Ultrasonik}

Untuk pengujian sensor ultrasonik dilakukan dengan menguji respon yang diberikan oleh sensor ultrasonik terhadap sampah yang berada di tempat sampah. Pengujian dilakukan dengan menghitung berapa jarak dari sampah ke sensor ultrasonik yang berada di tempat sampah. Pengujian sensor ultrasonik dilakukan dengan meletakkan sensor ultrasonik dibagian depan atas tempat sampah, untuk melihat keadaan tempat sampah kosong ataupun telah penuh terisi oleh sampah. Pada Gambar 12 dapat dilihat pengujian Sensor Ultrasonik.

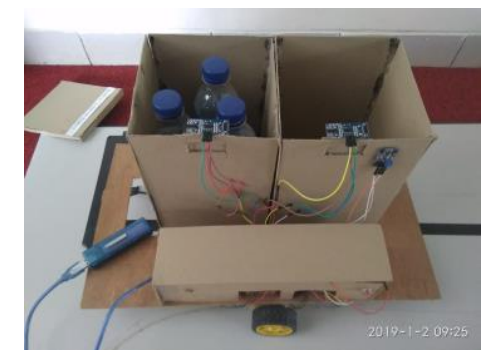

Gambar 12 Pengujian Sensor Ultrasonik

Untuk melihat hasil pengujian sensor ultrasonik secara keseluruhan,dapat dilihat pada tabel 3 berikut.

Tabel 3 Pengujian Sensor Ultrasonik

\begin{tabular}{|c|c|c|c|}
\hline $\begin{array}{c}\text { Jarak } \\
\text { Sebenar- } \\
\text { nya }(\mathrm{cm})\end{array}$ & $\begin{array}{c}\text { Jarak } \\
\text { Terdeteksi } \\
(\mathrm{cm})\end{array}$ & $\begin{array}{c}\text { Selisih jarak } \\
\text { terdeteksi } \\
\text { dan jarak } \\
\text { sebenarnya } \\
(\mathrm{cm})\end{array}$ & $\begin{array}{c}\text { Error } \\
(\%)\end{array}$ \\
\hline 2 & 2 & 0 & 0 \\
\hline 4 & 4 & 0 & 0 \\
\hline 5 & 6 & 1 & $16,7 \%$ \\
\hline 6 & 6 & 0 & 0 \\
\hline 7 & 7 & 0 & 0 \\
\hline & & & \\
\hline
\end{tabular}




\begin{tabular}{|c|c|c|c|}
\hline 9 & 9 & 0 & 0 \\
\hline 10 & 10 & 0 & 0 \\
\hline 11 & 11 & 0 & 0 \\
\hline 12 & 13 & 1 & $7.69 \%$ \\
\hline 16 & 16 & 0 & 0 \\
\hline \multicolumn{3}{|c|}{ Rata-rata Error } & $2.4 \%$ \\
\hline
\end{tabular}

Dari tabel 3 dapat dilihat bahwa sensor ultrasonik pada tempat sampah dapat membaca halangan pada tempat sampah.Dalam pembacaan sensor ultrasonik, terdapat selisih antara jarak sebenarnya dengan jarak yang dibaca oleh sensor ultrasonik dan mendapatkan nilai rata-rata Error keseluruhan $2.4 \%$.

$$
\begin{aligned}
& \% \text { Error }=\frac{(\text { nilaiterbala-nilaisebenarnya })}{\text { nilaiterba }} \times 100 \% \\
& \% \text { Error }=\left(\frac{6 \mathrm{~cm}-5 \mathrm{~cm}}{6 \mathrm{~cm}}\right) \times 100 \%=16.7 \%
\end{aligned}
$$

Error $=16.7 \%$

Namun nilai pengukuran tersebut tidak memiliki perbedaan yang terlalu berlebihan, Pada Gambar 13 dapat dilihat dengan grafik perbandingan hasil ukur jarak ultrasonik tersebut dibawah :

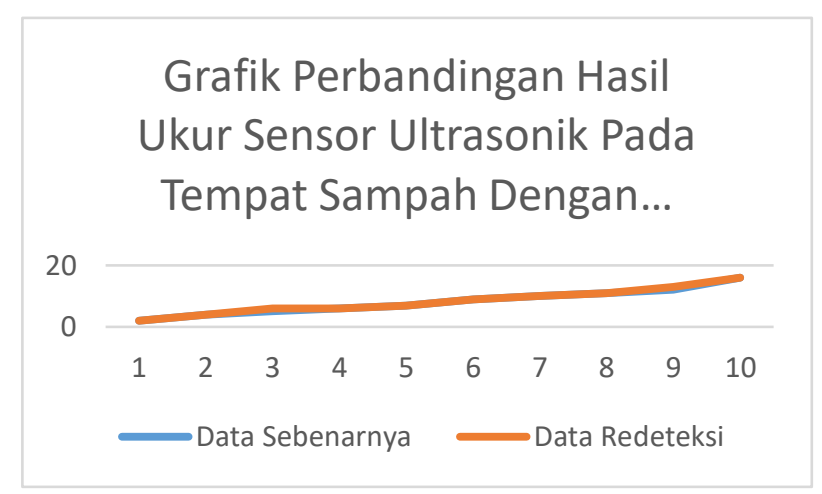

Gambar 13 Grafik Perbandingan Hasil Ukur Jarak Sampah dengan Ultrasonik dan Penggaris

Pada grafik analisa hasil diatas adalah pengujian sensor ultrasonik dengan penggaris dalam mengukur jarak sampah menunjukan perbedaan yang tidak terlalu jauh, dimana hasil pengujian dari kedua media ukur masih stabil dapat dilihat pada grafik dengan selisih yang tidak jauh bedanya dengan selisih paling tinggi $1 \mathrm{~cm}$.

Perbedaan pembacaan sensor ultrasonik dapat diakibatkan oleh beberapa faktor antara lain tipe sensor yang digunakan, jumlah tegangan dan arus yang tidak sesuai dalam rangkaian sensor tersebut. Namun dalam pembacaan sensor ini masih tergolong baik dengan perbedaan selisih pembacaan yang tidak terlalu besar dari jarak yang dideteksi sensor dengan jarak sebenarnya.

\section{Pengujian Sensor MQ-4}

Pengujian sensor gas mq-4 dilakukan untuk mengetahui sensor dapat bekerja atau tidak. Pengujian sensor gas mq-4 dilakukan dengan pada tempat sampah basah yang berisikan sampahsampah penyebab timbulnya $\mathrm{CH} 4$ yaitu semua produk yang dihasilkan oleh peternakan ini dikarenakan emisi metana dari peternakan merupakan salah satu penyumbang gas rumah kaca terbesar. Hewan seperti sapi dan domba, serta pembusukan sampah organik di tempat pembuangan, menyumbang dua pertiga metana yang dihasilkan [9]. Makanan yang berasal dari sektor peternakan misalnya adalah susu, daging dan lain-lain. Untuk percobaan Sensor MQ 4 pada tempat sampah basah akan dimasukkan susu sebanyak $200 \mathrm{ml}$ lalu akan diujikan berapa nilai ppm dari tempat sampah tersebut per satuan menit. Pada Gambar 14 dapat dilihat pengujian pada Sensor Metana MQ-4.

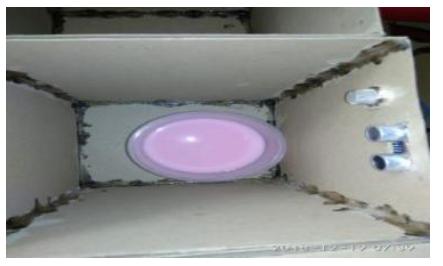

Gambar 14 Pengujian Sensor Metana MQ-4

Pada table 4 dapat dilihat hasil pengujian dari sensor gas mq-4.

Tabel 4 Hasil Pengujian Sensor Gas MQ-4

\begin{tabular}{|c|c|}
\hline Waktu (menit) & Nilai (PPM) \\
\hline 01.00 & 119 \\
\hline 02.00 & 138 \\
\hline 03.00 & 167 \\
\hline 04.00 & 178 \\
\hline 05.00 & 186 \\
\hline 06.00 & 193 \\
\hline 07.00 & 199 \\
\hline 08.00 & 204 \\
\hline 09.00 & 208 \\
\hline 10.00 & \\
\hline
\end{tabular}

Pada tabel di atas dapat dilihat bahwa nilai ppm di setiap menit beda-beda dan terus bertambah, Nilai ppm pada menit pertama dibaca oleh sensor MQ4 adalah 119 ppm dan terus bertambah

Clara Robert P. $\quad 85$ 
sampai pada menit ke sepuluh nilai ppm yang dapat terbaca oleh sensor adalah 208 ppm.

\section{Pengujian Sensor Photodioda}

Pengujian sensor Photodioda dilakukan untuk melihat respon pembacaan yang diberikan oleh sensor Photodioda dalam mendeteksi garis hitam atau putih. Pengujian sensor Photodiodadilakukan dengan meletakkan robot di posisi ketinggian tertentu kemudian mendekatkan sensor Photodioda robot pada beberapa jarak dari warna hitam atau putih tertentu yang ditentukan dari rute atau jalur.Dalam pengujian sensor photodioda ini dilakukan beberapa jarak yang ditentukandari rute atau jalur.Dalam pengujian sensor photodioda ini dilakukan beberapa jarak yang ditentukan, dapat dilihat pada gambar 15 berikut.

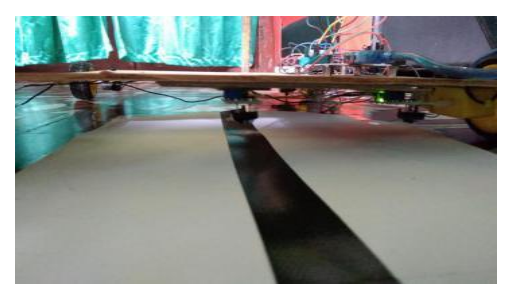

Gambar 15 Pengujian Sensor Photodiodapada jarak $2 \mathrm{~cm}$

Adapun hasil pembacaan Sensor Photodiodaberdasarkan hasil pengujian dapat dilihat pada tabel 5 berikut.

Tabel 5 Pengujian Sensor Photodioda

\begin{tabular}{|c|c|}
\hline Jarak & Keterangan \\
\hline $1 \mathrm{~cm}$ & Terdeteksi \\
\hline $2 \mathrm{~cm}$ & Terdeteksi \\
\hline $3 \mathrm{~cm}$ & Terdeteksi \\
\hline $4 \mathrm{~cm}$ & Terdeteksi \\
\hline $5 \mathrm{~cm}$ & Terdeteksi \\
\hline $6 \mathrm{~cm}$ & Tidak Terdeteksi \\
\hline $7 \mathrm{~cm}$ & Tidak Terdeteksi \\
\hline $8 \mathrm{~cm}$ & Tidak Terdeteksi \\
\hline $9 \mathrm{~cm}$ & Tidak Terdeteksi \\
\hline $10 \mathrm{~cm}$ & \\
\hline
\end{tabular}

Dari tabel 5 dapat dilihat bahwa sensor Photodioda dapat membaca adanya warna pada jarak tertentu.pada jarak 1-5 cm, sensor photodioda dapat mendeteksi warna hitam.Sedangkan

Clara Robert $\mathrm{P}$. pada jarak 6-10 cm, sensor photodioda tidak dapat mendeteksi warna hitam hal ini dikarenakan batas maksimal pembacaan sensor photodioda adalah $5 \mathrm{~cm}$ [13]. Perbedaan pembacaan sensor Photodioda dapat diakibatkan oleh beberapa faktor antara lain karena intensitas cahaya yang tidak masuk ke Photodioda, bisa juga dikarenakan jumlah tegangan dan arus yang tidak sesuai dalam rangkaian sensor tersebut.

\section{Pengujian Motor DC, Roda dan Catu Daya}

Pengujian Motor DC, Roda dan Catu Daya dilakukan untuk mengetahui Motor DC dapat bekerja atau tidak dalam menggerakkan roda serta pengujian dilakukan untuk melihat apakah Catu daya dapat bekerja atau tidak. Pengujian Motor DC, Roda serta catu daya dilakukan dengan menghitung kecepatan waktu pergerakkan robot pada setiap jarak yang berbeda dimulai dengan jarak yang paling pendek yaitu $50 \mathrm{~cm}$ sampai jarak terjauh yaitu $350 \mathrm{~cm}$. Pengujian Motor DC, Roda serta Catu Daya dapat dilihat pada gambar 16 berikut.

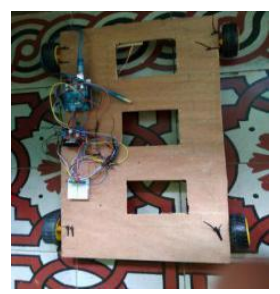

Gambar 16 Pengujian Motor DC, Roda dan Catu Daya

Pada tabel 6 dapat dilihat hasil pengujian dari Motor DC, Roda dan Catu Daya

Tabel 6 Pengujian Motor DC, Roda dan Catu Daya

\begin{tabular}{|c|c|}
\hline Jarak $(\mathrm{cm})$ & Waktu (detik) \\
\hline $50 \mathrm{~cm}$ & 03.06 \\
\hline $80 \mathrm{~cm}$ & 05.00 \\
\hline $100 \mathrm{~cm}$ & 07.06 \\
\hline $120 \mathrm{~cm}$ & 08.03 \\
\hline $150 \mathrm{~cm}$ & 09.04 \\
\hline $200 \mathrm{~cm}$ & 10.08 \\
\hline $220 \mathrm{~cm}$ & 13.08 \\
\hline $250 \mathrm{~cm}$ & 14.04 \\
\hline $300 \mathrm{~cm}$ & 17.02 \\
\hline $350 \mathrm{~cm}$ & \\
\hline
\end{tabular}


Pada tabel di atas dapat dilihat bahwa kecepatan waktu disetiap panjang lintasan berbeda-beda waktu paling kecil didapatkan pada jarak paling pendek yaitu lintasan dengan panjang $50 \mathrm{~cm}$ dapat dilalui dengan waktu 03.05 detik sedangkan waktu tempuh paling lama didapatkan pada jarak paling panjang yaitu lintasan dengan panjang $350 \mathrm{~cm}$ dapat dilalui dengan waktu 17.02 detik.

\section{Pengujian Driver Motor}

Pengujian Driver Motor dilakukan untuk mengetahui Driver dapat berkerja dengan baik atau tidak . Pengujian Driver Motor dilakukan dengan meletakkan beban berupa sampah dengan berat yang berbeda-beda di atas robot pengangkut sampah dimulai dari berat yang paling rendah yaitu sampai berat yang paling besar dan akan dilihat seberapa lama robot akan melaju mengikuti jalur dari titik awal sampai dengan titik akhir. Jalur Pengujian Driver Motor dapat dilihat pada gambar 17 berikut.

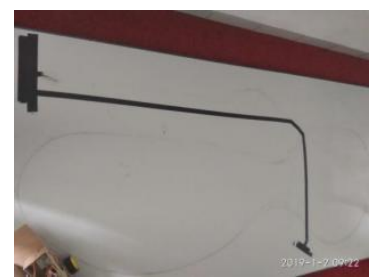

Gambar 17 Jalur Pengujian Driver Motor

Pengujian Driver Motor yang dilakukan dengan beban sampah berbeda-beda dapat dilihat pada gambar 18berikut.

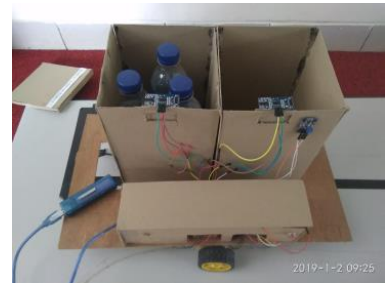

Gambar 18 Pengujian Driver Motor

Pada tabel 7 dapat dilihat hasil pengujian dari Driver Motor

Tabel 7 Pengujian Driver Motor

\begin{tabular}{|c|c|c|}
\hline Objek & $\begin{array}{c}\text { Beban } \\
\text { (gram) }\end{array}$ & Waktu (Detik) \\
\hline $\begin{array}{c}\text { Kaleng Minuman } \\
\text { Bekas }\end{array}$ & 90 & 55 \\
\hline $\begin{array}{c}\text { Botol Minuman } \\
\text { Plastik }\end{array}$ & 100 & 55 \\
\hline $\begin{array}{c}\text { Sosis dan Keju } \\
\text { Sisa }\end{array}$ & 100 & 55 \\
\hline
\end{tabular}

https://doi.org/10.25077/jitce.3.02.78-89.2019

\begin{tabular}{|c|c|c|}
\hline $\begin{array}{c}\text { Kotak Makanan } \\
\text { Bekas }\end{array}$ & 110 & 62 \\
\hline $\begin{array}{c}\text { Kaleng Minuman } \\
\text { Bekas }\end{array}$ & 130 & 80 \\
\hline Susu Sapi & 161 & 100 \\
\hline
\end{tabular}

Pada tabel di atas dapat dilihat bahwa kecepatan waktu disetiap beban sampah berbeda-beda waktu paling kecil didapatkan pada beban paling ringan yaitu dengan beban 90 gram dapat dilalui dengan waktu 45 detik sedangkan waktu tempuh paling lama didapatkan pada beban paling berat yaitu sampah dengan beban 161 gram dapat dilalui dengan waktu 100 detik.

\section{Pengujian Sistem Kontrol Robot Secara Keseluruhan}

Pengujian sistem kontrol robot dilakukan untuk melihat proses keseluruhan dari sistem kontrol robot mulai dari pembacaan sensor Ultrasonik dan sensor MQ-4 dalam memonitoring setiap tempat sampah, pembacaan sensor Photodioda dalam mendeteksi jalur diarena yang ditentukan dan mengikuti garis, serta keseluruhan proses pada sistem kontrol robot tempat penampung sampah ini.

Arena pengujian yang digunakan berupa arena yang hanya di buat sebagai arena prototipe untuk digunakan dalam melakukan segala fungsi robot pengumpul sampah dengan jalur garis hitam yang terdiri dari jalur lurus serta jalur belok ke arah kanan seperti tampak pada gambar 19 Jalur ini akan dilewati oleh robot ketika tempat sampah telah terisi penuh atau telah terdapat kadar gas metana berbahaya didalam tempat sampah.

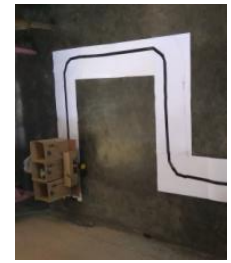

Gambar 19 Jalur Robot Keseluruhan

Dalam melewati jalur robot dengan mengikuti garis pada jalur dan menggunakan sensor Photodioda yang ada pada sisi depan bawah dari robot. Sensor Photodioda ang ada pada robot berfungsi untuk menjaga posisi robot tetap pada saat bernavigasi di jalur pengujian. Pada gambar 20 dilihat robot pengumpul sampah berada pada posisi awal. 


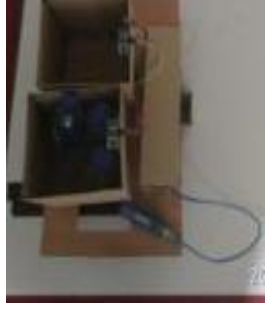

A. Sampah Kering

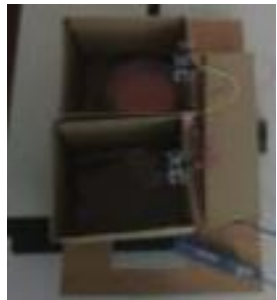

B.Sampah Basah
Gambar 20 Robot Pengumpul Sampah di Jalur Awal

Pada gambar 20 dapat dilihat ada 2 jenis sampah pada 2 tempat sampah yaitu tempat sampah kering yang berisi botol plastik dan tempat sampah basah telah berisi susu sapi. Kedua tempat sampah telah terisi penuh atau telah mengandung kadar gas metana dan akan berjalan melewati jalur menuju tempat pemberhentian. Adapun hasil pengujian sistem kontrol robot secara keseluruhan dapat dilihat pada tabel 8 berikut.

Tabel 8 Pengujian Secara Keseluruhan

\begin{tabular}{|c|c|c|c|c|}
\hline $\begin{array}{l}\text { Pengu- } \\
\text { jian }\end{array}$ & $\begin{array}{l}\text { Objek } \\
\text { Peneliti- } \\
\text { an }\end{array}$ & $\begin{array}{l}\text { Berat } \\
\text { Beban }\end{array}$ & $\begin{array}{l}\text { Waktu } \\
\text { tempuh }\end{array}$ & $\begin{array}{l}\text { Ketera- } \\
\text { ngan }\end{array}$ \\
\hline 1 & $\begin{array}{l}\text { Botol } \\
\text { Plastik } \\
\text { Bekas }\end{array}$ & 150 gram & 79 detik & $\begin{array}{l}\text { Robot } \\
\text { berhasil } \\
\text { melakukan } \\
\text { semua } \\
\text { permintaan } \\
\text { dari } \\
\text { skenario } \\
\text { pengujian } \\
\text { dengan } \\
\text { beban } 150 \\
\text { gram dan } \\
\text { waktu } \\
\text { yang di } \\
\text { tempuh } \\
\text { dengan } 75 \\
\text { detik. } \\
\text { Sensor } \\
\text { Photodiod } \\
\text { a, sensor } \\
\text { ultrasonik } \\
\text { dan sensor } \\
\text { MQ-4 } \\
\text { berfungsi } \\
\text { dengan } \\
\text { baik. }\end{array}$ \\
\hline 2 & $\begin{array}{l}\text { Kaleng } \\
\text { Rokok } \\
\text { Bekas }\end{array}$ & 280 gram & 99 detik & $\begin{array}{l}\text { Robot } \\
\text { berhasil } \\
\text { melakukan } \\
\text { semua }\end{array}$ \\
\hline
\end{tabular}

\begin{tabular}{|c|c|c|c|c|}
\hline & & & & $\begin{array}{l}\text { permintaan } \\
\text { dari } \\
\text { skenario } \\
\text { pengujian } \\
\text { dengan } \\
\text { beban } 280 \\
\text { gram dan } \\
\text { waktu } \\
\text { yang di } \\
\text { tempuh } \\
\text { dengan } 99 \\
\text { detik. } \\
\text { Sensor } \\
\text { Photodiod } \\
\text { a, sensor } \\
\text { ultrasonik } \\
\text { dan sensor } \\
\text { MQ-4 } \\
\text { berfungsi } \\
\text { dengan } \\
\text { baik }\end{array}$ \\
\hline 3 & $\begin{array}{l}\text { Sisa Susu } \\
\text { Sapi }\end{array}$ & 320 gram & 145 detik & $\begin{array}{l}\text { Robot } \\
\text { berhasil } \\
\text { melakukan } \\
\text { semua } \\
\text { permintaan } \\
\text { dari } \\
\text { skenario } \\
\text { pengujian } \\
\text { dengan } \\
\text { beban } 320 \\
\text { gram dan } \\
\text { waktu } \\
\text { yang di } \\
\text { tempuh } \\
\text { dengan } \\
145 \text { detik. } \\
\text { sensor } \\
\text { Photodiod } \\
\text { a, sensor } \\
\text { ultrasonik } \\
\text { dan sensor } \\
\text { MQ-4 } \\
\text { berfungsi } \\
\text { dengan } \\
\text { baik }\end{array}$ \\
\hline 4 & $\begin{array}{l}\text { Push } \\
\text { Button }\end{array}$ & 0 gram & 60 detik & $\begin{array}{l}\text { Robot } \\
\text { berhasil } \\
\text { melakukan } \\
\text { semua } \\
\text { permintaan } \\
\text { dari } \\
\text { skenario } \\
\text { pengujian } \\
\text { dengan } \\
\text { beban } 0 \\
\text { gram dan } \\
\text { waktu }\end{array}$ \\
\hline
\end{tabular}

https://doi.org/10.25077/jitce.3.02.78-89.2019 


\begin{tabular}{|l|l|l|l|}
\hline & & & yang di \\
tempuh \\
dengan 60 \\
detik. Push \\
Button \\
berfungsi \\
dengan \\
baik
\end{tabular}

Pengujian diatas dilakukan 4 kali pengujian dengan kondisi

1. Tempat Sampah Kering telah terisi penuh oleh botol plastik bekas seberat 150 gram.

2. Tempat Sampah Kering telah terisi penuh oleh kaleng rokok bekas seberat 280 gram.

3. Tempat Sampah Basah telah terisi penuh oleh sisa minuman susu seberat 320 gram

4. Push Button yang bernilai HIGH dengan 0 gram beban

Dari pengujian table 8 telah didapatkan total keberhasilan 4 dari 4 kali percobaan Hasil pengujian secara keseluruhan menunjukkan bahwa waktu tempuh robot yang paling singkat adalah robot pada tempat sampah kering dengan beban berupa botol plastik bekas dengan berat 150 gram dengan waktu tempuh 79 detik dan waktu tempuh paling paling lama adalah robot pada tempat sampah basah dengan beban sampah berupa sisa susu sapi dengan berat 320 gram serta waktu tempuh 145 detik.

\section{KESIMPULAN}

1. Hasil pengujian sensor ultrasonik menunjukkan terdapat error atau selisih antara jarak sebenarnya dengan jarak pembacaan sensor dengan presentase error mencapai $2.4 \%$. tetapi jarak yang terukur masih mendekati dengan jarak yang sebenarnya.Pengujian sensor MQ-4 menunjukkan bahwa sensor dapat mendeteksi kadar gas metana yang berada di tempat sampah basah yang berisikan susu sapi $200 \mathrm{ml}$ dengan nilai $208 \mathrm{ppm}$ pada menit kesepuluh pengujian.

2. Arduino UNO mampu memproses hasil monitoring yang telah dilakukan oleh sensor ultrasonik dan sensor gas metana MQ-4 pada tempat sampah dengan tingkat kerberhasilan 3 dari 3 kali percobaan dimana percobaan pertama dan percobaan kedua merupakan hasil inputan dari sensor ultrasonik sedangkan percobaan ketiga merupakan hasil inputan dari sensor MQ-4.

3. Pengujian sensor Photodioda menunjukkan bahwa sensor dapat menangkap atau membaca garis dengan jarak $1-5 \mathrm{~cm}$ sedangkan pada jarak $6 \mathrm{~cm}$ dan seterusnya sensor photodioda tidak dapat mendeteksi garis hitam hal itu dikarenakan jarak maksimal pembacaan dari sensor adalah $5 \mathrm{~cm}$. Arduino UNO juga mampu memproses hasil inputan dari sensor photodioda dengan tingkat keberhasilan 4 dari 4 kali percobaan dimana robot dapat berjalan melewati denah jalur dengan waktu tempuh paling cepat yaitu sampah kering dengan beban 150 gram dapat melewati denah jalur dengan waktu tempuh 79 detik dan waktu tempuh paling lama yaitu sampah basah dengan beban 320 gram dapat melewati denah jalur dengan waktu tempuh 145 detik.

\section{REFERENCES}

[1] Faisal.2017. Aplikasi Smart Trash Can Dalam Mengatasi Persoalan Sampah Secara Mobile Berbasis Android. Jurnal Teknik Informatika. Makassar : UIN Alaudin Makassar.

[2] Ohoiwutun, Johanes.2018. Analisis dan Perancangan Smart Dump menggunakan Arduino Mega 2560 Rev3 dan GSM SIM900. Jurnal Teknik Elektro. Sorong : Politeknik Katolik Saint Paul Sorong.

[3] Galina, Lina. Umar, Ulfa Dwinda. 2016. Smart Trash Bin With Solar Cell. Jurnal Fakultas Teknik. Bekasi : President University.

[4] Pitoyo, Cahyadi. 2017. Studi Komposisi Sampah Perkotaan Pada Tingkat Rumah Tangga di kota Depok. Depok : Universitas Gunadarma.

[5] Nugraha K, Fandhi. 2016. Tugas Sensor Ultrasonik. Makassar : Universitas Hasanuddin.

[6] Ultrasonic Ranging HC-SR04, www.Elecfreaks.com.Diakses pada tanggal 28Mei 2018, pukul 06.56 WIB.

[7] Anisa, Ona. 2017. Rancang Bangun Pengukur Kadar Gas Methana Pada Lahan Gambut Menggunakan SMS Gateway dan Sensor MQ-4 Berbasis Mikrokontroler. Palembang : Polikteknik Negeri Surabaya.

[8] Nisa Saputri, Zaratul. 2014. Aplikasi Pengenalan Suara Sebagai Pengendali Peralatan Listrik Berbasis Arduino Uno. Malang : Universitas Brawijaya.

[9] Bhatt,Zayani.https://today.mims.com/efek-limbahmakanan-terhadap-kehidupan-di-dunia. Diakses pada tanggal 9 November 2018, pukul 10.39 WIB

[10] Fatah Fatchurrohman, Amir.2014. Robot Line Follower PID Sebagai Media Pembelajaran Aplikasi Mikrokontroler di Jurusan Pendidikan Teknik Elektronika Fakultas Teknik Universitas Yogyakarta. Yogyakarta : Universitas Negeri Yogyakarta.

[11] Politeknik Negri Sriwijaya, http://eprints.polsri.ac.id. Diakses pada tanggal 9 Oktober 2018, pukul 17.56 WIB.

[12] Prayogo, Rudito. 2012. Pengaturan PWM dengan PLC. Malang : Universitas Brawijaya.

[13] Sunrom Electronics.

https://www.sunrom.com/p/lineobstacle-sensortcrt5000. Diakses pada tanggal 9 November 2018, pukul 09.28 WIB 